\title{
HUBUNGAN PERILAKU KEBERSIHAN PERORANGAN DENGAN KECACINGAN PADA SISWA SD SUSUKAN KECAMATAN SUMBANG KABUPATEN BANYUMAS
}

\section{CORRELATION BETWEEN PERSONAL HYGIENE BEHAVIOR AND HELMINTHIASIS OF SUSUKAN'S ELEMENTARY SCHOOL STUDENTS, SUMBANG, BANYUMAS}

\author{
Octavia Permata Sari ${ }^{1 *}$, Tutik Ida Rosanti, Lieza Dwianasari Susiawan \\ *Departemen Parasitologi, Fakultas Kedokteran, Universitas Jenderal Soedirman \\ Jalan.Dr. Gumbreg No.1
}

\begin{abstract}
ABSTRAK
Kecacingan merupakan salah satu penyebab infeksi yang sering dijumpai di negara tropis, seperti Indonesia. Gejala kecacingan yang tidak khas menyebabkan keberadaan cacing di dalam tubuh penderita tidak diketahui dan sering diabaikan. Kecamatan Sumbang, Kabupaten Banyumas merupakan salah satu daerah yang memiliki faktor risiko infeksi kecacingan khususnya Soil Transmitted Helmiths (STHs) pada anak. Penelitian ini bertujuan untuk mengetahui prevalensi kecacingan dan hubungan perilaku kebersihan perorangan dengan kejadian kecacingan pada siswa SD Susukan, Kecamatan Sumbang, Kabupaten Banyumas. Identifikasi telur cacing parasit usus dilakukan menggunakan pemeriksaan feses metode apung. Uji Chi square dilakukan untuk melihat adanya hubungan antara variabel perilaku kebersihan perorangan siswa SD Susukan dengan kejadian infeksi kecacingan. Prevalensi kecacingan di SD Susukan, Kecamatan Sumbang, Kabupaten Banyumas adalah sebesar 6,8\% dengan spesies yang ditemukan adalah A. lumbricoides dan Hymenolepis sp. Tidak terdapat hubungan antara variabel perilaku kebersihan perorangan siswa SD dengan kejadian infeksi kecacingan $(p=0,197)$.

Kata kunci: Ascaris lumbricoides, kecacingan, STHs
\end{abstract}




\section{ABSTRACT}

Helminthiasis is one of the causes of infection that is often found in tropical countries, such as Indonesia. Symptoms of worm infection almost unspesific, so the presence of worms in the patient's body is unknown and often neglected. Sumbang, Banyumas Regency has risk factors that potentialy support the occurrence of Soil Transmitted Helminths (STHs) infections especially in children. This study aims to determine the prevalence of helminthiasis and the association between personal hygiene behavior with helminthiasis in Susukan Elementary School students, Sumbang, Banyumas. Worm infection is detected by fecal examination of the floating method. Chi square test was conducted to assess the correlation between personal hygiene behavioral of Elementary school of Susukan students and the incidence of helminthiasis. The prevalence of helminthiasis in Susukan Elementary School, Sumbang, Banyumas is about 6.8\%. The species were $A$. lumbricoides and Hymenolepis sp. There was no correlation between the personal hygiene behavioral variables of elementary school students and the incidence of helminthiasis $(\mathrm{p}=0,197)$.

Keywords: Ascaris lumbricoides, Helminthiasis, STHs

\section{Penulis korespondesi:}

Octavia Permata Sari

Departemen Parasitologi,Universitas Jenderal Soedirman

Jln.Dr.Gumbreg No.1

Email:octavia.murdani@gmail.com

\section{PENDAHULUAN}

Kecacingan merupakan suatu permasalahan kesehatan yang masih dijumpai pada masyarakat khususnya yang tinggal di negara tropis seperti Indonesia. Sebagai negara beriklim tropis, Indonesia memiliki iklim dan kelembaban yang mendukung parasit cacing untuk tetap melangsungkan hidupnya (Sandi et al., 2015). Telur cacing yang keluar bersama dengan feses dapat berkembang menjadi larva atau stadium infektif lainnya pada kondisi tanah liat dan tanah dengan kelembaban tinggi serta terlindung dari pancaran sinar matahari secara langsung (Bisara dan Mardiana, 2014). Pada kasus yang ringan, kecacingan biasanya tidak memberi gejala yang nyata dan spesifik. Gejala yang sering dijumpai pada infeksi kecacingan antara lain lemah, mudah lesu, sering mengantuk, badan tampak kurus karena kekurangan nutrisi penting untuk tubuh (Yusriati, 2016).

Infeksi kecacingan yang sering dijumpai pada manusia adalah cacing yang dalam siklus hidupnya melalui tanah dan disebarkan melalui kontak dengan tanah. Jenis cacing ini dikenal dengan Soil Transmitted Helminths (STHs). Spesies STHs yang sering menyebabkan morbiditas pada manusia adalah A. lumbricoides, Trichuris trichiura dan Necator americanus. Sebesar 4,5 milyar penduduk di dunia memiliki risiko terinfeksi STHs, 10\% diantaranya mengalami infeksi yang berat dan sebagian besar diantaranya adalah anak-anak. Tidak kurang dari 135.000 jiwa meninggal karena infeksi cacing khususnya A. lumbricoides (Vercruysse et al., 2011). Pemeriksaan feses yang dilakukan di beberapa wilayah menunjukan angka kejadian yang bervariasi karena bergantung pada kondisi lingkungan dan perbedaan kebiasaan perilaku hidup sehat tiap individu. 
Sebagai parasit usus tidak hanya mengambil zat makanan penting yang ada di dalam tubuh manusia tetapi juga dapat menimbulkan kerusakan pada mukosa usus. Hal ini akan menyebabkan gangguan penyerapan nutrisi pada penderita kecacingan (Manuhutu et al., 2017). Gangguan penyerapan nutrisi secara berkepanjangan akan menyebabkan penderita mengalami kekurangan nutrisi penting yang dibutuhkan untuk pertumbuhan dan perkembangan anak. Hal ini tentunya akan mengurangi kualitas sumber daya manusia. Pada infeksi A. lumbricoides yang berat dapat menimbukan kondisi kegawatdaruratan dikarenakan koloni cacing ini menyebabkan kondisi yang disebut dengan ileus obstruktif (Sardjono et al, 2017).

Infeksi kecacingan lebih sering dijumpai pada anak baik itu usia pra sekolah ataupun sekolah dasar. Hal ini disebabkan karena aktifitas anak yang sering kontak dengan tanah. Tercemarnya tanah oleh telur cacing akibat kurangnya kesadaran akan kebersihan menjadi penyebab infeksi kecacingan menjadi sulit diberantas. STHs dapat menginfeksi manusia melalui tangan dan kuku kotor yang tercemar oleh telur cacing setelah anak kontak dengan tanah (Chadijjah et al., 2014).

Kecacingan di Indonesia masih sering dijumpai pada daerah yang memiliki tingkat pengetahuan dan personal higiene yang kurang, sosial ekonomi rendah dan sanitasi lingkungan yang buruk. Sanitasi lingkungan yang berkaitan dengan kejadian kecacingan meliputi ketersediaan sumber air bersih dan ketersediaan jamban di rumah atau lingkungan (Ziegelbauer et al., 2012). Kebiasaan masyarakat yang sering tidak menggunakan alas kaki dan tidak terbiasa mencuci tangan merupakan faktor risiko infeksi kecacingan (Sandy et al., 2015).

Berdasarkan pengamatan peneliti, siswa Sekolah Dasar (SD) Susukan, Sumbang, Banyumas masih memiliki kebersihan diri yang buruk. Terlihat dari kebiasaan tidak menggunakan alas kaki pada saat bermain maupun ke sekolah. Selain itu, tidak setiap rumah tangga memiliki jamban keluarga.

Berdasarkan latar belakang tersebut perlu dilakukan penelitian untuk mencari hubungan antara perilaku kebersihan perorangan dengan kecacingan pada siswa SD Susukan, Sumbang, Banyumas.

\section{METODE PENELITIAN}

Jenis penelitian ini adalah deskriptif analitik, dengan desain penelitian cross sectional. Penelitian dilakukan di SD Susukan, Kecamatan Sumbang, Kabupaten Banyumas pada bulan Maret sampai dengan April tahun 2017. Populasi penelitian adalah siswa SD kelas 3, 4 dan 5. Metode pengambilan sampel yang digunakan adalah total sampling. Jumlah sampel pada penelitian ini adalah 44. Data penelitian mengenai perilaku kebersihan perorangan diambil melalui kuesioner dan data mengenai diagnosis kecacingan diperoleh melalui pemeriksaan feses.

\section{Alat dan Bahan}

Diagnosis kecacingan ditegakkan dengan identifikasi telur parasit usus pada feses dengan metode apung. Bahan yang digunakan adalah $\mathrm{NaCl}$ jenuh (33\%). Identifikasi telur cacing dilakukan dengan menggunakan mikroskop cahaya dengan perbesaran okuler 10x dan objektif 40x.

\section{Jalannya Penelitian}

1. Pengambilan sampel feses

Pengambilan sampel feses pada setiap responden dilakukan menggunakan wadah pot plastik volume $50 \mathrm{ml}$ yang bersih. Sebelum pot spesimen dibagikan kepada siswa, peneliti terlebih dahulu memberikan penjelasan kepada orangtua siswa mengenai cara pengambilan feses. Feses diambil 
kurang lebih 10 gram atau sebesar satu ruas ibu jari, tidak tercampur dengan urin, tanah ataupun air. Sampel feses bisa langsung diidentifikasi atau disimpan pada suhu $4^{\circ} \mathrm{C}$ atau diletakkan di dalam box yang berisi es batu.

2. Pemeriksaan feses

Pemeriksaan feses dilakukan di Laboratorium Parasitologi Fakultas Kedokteran Universitas Jenderal Soedirman secara kualitatif dengan metode apung. Masing-masing sampel dilakukan pengamatan secara duplo untuk memperkuat hasil pengamatan.

3. Pengambilan data perilaku kebersihan perorangan siswa

Data mengenai perilaku kebersihan perorangan siswa SD Susukan yang berkaitan dengan kejadian kecacingan diperoleh diukur menggunakan kuesioner. Pengisian kuesioner dilakukan dengan teknik wawancara kepada siswa dengan didampingi oleh orangtua.

\section{Analisis Data}

Analisis data menggunakan statistik univariat untuk melihat prevalensi kecacingan pada responden serta untuk mengetahui data distribusi responden yang terinfeksi kecacingan. Analisis bivariat menggunakan statistik Chi square dilakukan untuk melihat adanya hubungan antara perilaku kebersihan perorangan siswa SD dengan kejadian infeksi cacing parasit usus.

\section{HASIL DAN PEMBAHASAN}

Karakteristik responden pada penelitian ini dapat dilihat pada Tabel I. Sampel penelitian ini meliputi seluruh siswa kelas 3, 4 dan 5 SD dengan total responden yang sebanyak 44 orang. Dari 44 orang tersebut, 15 anak merupakan siswa kelas 3. Siswa kelas 4 berjumlah 15 anak dan 14 anak lainnya merupakan siswa kelas 5 SD Susukan.

Tabel I. Karakteristik responden

\begin{tabular}{ccccc}
\hline \multirow{2}{*}{ Kelas } & \multicolumn{2}{c}{ Jumlah siswa } & \multicolumn{2}{c}{ Telur cacing $(+)$} \\
\cline { 2 - 5 } & Laki-laki & Perempuan & Laki-laki & Perempuan \\
\hline III & 8 & 7 & 2 & 0 \\
IV & 13 & 2 & 1 & 0 \\
V & 11 & 3 & 0 & 0 \\
Total & 32 & 12 & 3 & 0 \\
\hline
\end{tabular}

Berdasarkan jenis kelamin, 32 orang responden berjenis kelamin laki-laki (72,7\%) dan 12 orang berjenis kelamin perempuan $(27,3 \%)$. Pada penelitian ini didapatkan telur cacing parasit usus sebanyak 3 dari 44 sampel (6,8\%). Spesies cacing parasit usus yang teridentifikasi adalah $A$. lumbricoides (66,7\%) dan Hymenolepis sp (33,3\%). A. lumbricoides merupakan salah satu jenis STHs yang sering dijumpai dan menginfeksi manusia. Penelitian yang sama dilakukan oleh Muthoharah et al., (2015) di Kecamatan Petanahan, Kabupaten Kebumen, dengan prevalensi kecacingan mencapai $45,1 \%$ dengan $71,2 \%$ adalah $A$. lumbricoides. Penelitian di Palu menunjukkan angka kejadian ascariasis di kota Palu mencapai 83,34\% dari total angka kecacingan disana. Sebagai daerah tropis, iklim di Indonesia sangat mendukung perkembangan telur cacing untuk menjadi stadium infektif (Chadijjah et al., 2014). 
Telur A. lumbricoides diidentifikasi dengan ciri morfologinya yang khas yakni memiliki 3 lapisan dinding. Lapisan telur A. lumbricoides dari luar ke dalam yaitu albuminoid (merupakan lapisan yang bergelombang), kitin, dan vitelin. Ketiga lapisan ini dapat mudah teridentifikasi pada telur yang normal dan fertil. Pada telur yang mengalami dekortikasi akan kehilangan lapisan albuminoid sehingga tampak hanya memiliki 2 lapisan saja yakni kitin dan vitelin. Telur infertil adalah telur yang tidak memiliki potensi untuk berkembang menjadi tahap selanjutnya. Telur infertil memiliki bentuk yang lebih lonjong dan lebih besar daripada telur normal. Telur infertil tiak memiliki lapisan vitelin. Telur Hymenolepis sp. diidentifikasi dari ciri morfologi bentuknya yang bulat atau oval. Membran luar dari telur bergaris radier dan isi dari telur merupakan onkosfer yang memiliki kait (Sardjono et al, 2017).

Hasil penelitian ini menunjukkan telur cacing masih ditemukan pada feses siswa SD Susukan, Sumbang, Banyumas sebanyak 6,8\%. Faktor yang mempengaruhi kejadian kecacingan meliputi kebiasaan pola hidup bersih dari masing-masing individu dan juga kondisi sanitasi lingkungan (Thomas et al., 2014). Adanya kejadian kecacingan di lokasi penelitian dapat mengindikasikan bahwa kesadaran masyarakat akan kebersihan diri dan lingkungan masih kurang (Martila et al., 2015). Data perilaku individu dapat dilihat pada tabel II.

Tabel II. Data perilaku kebersihan mandiri responden

\begin{tabular}{|c|c|c|c|}
\hline No & Perilaku & Jumlah & $\%$ \\
\hline \multirow[t]{4}{*}{1} & Anak sering bermain dengan tanah & & \\
\hline & Ya & 24 & 54,5 \\
\hline & Kadang-kadang & 13 & 29,5 \\
\hline & Tidak & 7 & 15,9 \\
\hline \multirow[t]{4}{*}{2.} & Selalu mencuci tangan setelah bermain tanah & & \\
\hline & Ya & 30 & 68,2 \\
\hline & Kadang-kadang & 10 & 22,7 \\
\hline & Tidak & 4 & 9,1 \\
\hline \multirow[t]{4}{*}{3} & Selalu mencuci tangan sebelum makan & & \\
\hline & Ya & 31 & 70,5 \\
\hline & Kadang-kadang & 11 & 25,0 \\
\hline & Tidak & 2 & 4,5 \\
\hline \multirow[t]{3}{*}{4} & Air yang digunakan untuk mencuci tangan & & \\
\hline & Air kobokan & 2 & 4,5 \\
\hline & Air mengalir & 42 & 95,5 \\
\hline \multirow[t]{4}{*}{5} & Kebiasaan mencuci tangan setelah BAB & & \\
\hline & Ya & 39 & 88,6 \\
\hline & Kadang-kadang & 2 & 4,5 \\
\hline & Tidak & 3 & 6,8 \\
\hline \multirow[t]{4}{*}{6} & Frekuensi anak memotong kuku & & \\
\hline & 1x/minggu & 35 & 79,5 \\
\hline & $1 \mathrm{x} / 2$ minggu & 7 & 15,9 \\
\hline & $>2$ minggu sekali & 2 & 4,5 \\
\hline
\end{tabular}


7 Kebiasaan menggigit kuku

Kadang-kadang

Tidak

1125,0

$4 \quad 9,1$

Kebiasaan menghisap jari

$29 \quad 65,9$

Ya

$5 \quad 11,4$

Tidak

$39 \quad 88,6$

9 Kebiasaan memakai alas kaki ketika diluar rumah

Ya

Kadang-kadang

Tidak

$31 \quad 70,5$

$8 \quad 18,2$

$5 \quad 11,4$

10 Anak sering bermain di sungai/parit/selokan

Ya

$15 \quad 61,4$

Tidak

$17 \quad 38,6$

8 Kebiasaan BAB di sungai

Ya

$11 \quad 25,0$

Tidak

$33 \quad 75,0$

Berdasarkan tabel II. dapat dilihat bahwa dari 44 responden, 54,5\% anak memiliki kebiasaan bermain di luar rumah dan sering kontak dengan tanah, sedangkan sisanya hanya sesekali waktu. Spesies STHs yang ditemukan pada penelitian ini adalah A. lumbricoides. Sebagai daerah yang memiliki tanah subur, tanah di Kecamatan Sumbang merupakan area yang mendukung cacing STHs untuk berkembang menjadi stadium infektif. Oleh karena itu, kebiasaan bermain dan kontak dengan tanah bisa menjadi salah satu faktor risiko kejadian kecacingan di wilayah Kecamatan ini. Hasil penelitian menunjukkan bahwa masih dijumpai responden yang tidak mencuci tangan setelah bermain dan kontak dengan tanah sebesar 9,1\%, dan 22,7\% hanya sesekali mencuci tangan setelah bermain dan kontak dengan tanah. Kebiasaan tidak mencuci tangan setelah bermain dan kontak dengan tanah akan memperbesar kemungkinan masuknya telur atau stadium infektif lainnya dari cacing parasit ke dalam tubuh manusia (Chadijjah et al., 2014).

Hasil penelitian menunjukkan sebesar $70,5 \%$ responden memiliki kebiasaan mencuci tangan sebelum makan. Hal ini merupakan kebiasaan baik yang harus terus digalakkan pada masyarakat untuk memutus rantai penularan infeksi kecacingan yang salah satu jalur penularannya melalui oral. Sebanyak 95,5\% responden telah menggunakan air mengalir untuk mencuci tangan. Hanya $4,5 \%$ responden yang terbiasa mencuci tangan dengan air dalam wadah. Dengan kebiasaan mencuci tangan menggunakan air yang mengalir diharapkan agen infeksi berupa telur infektif dapat terbawa air dan tidak menempel pada tangan sehingga transmisi dari satu penderita ke orang lain juga dapat dihindari (Aswadi et al., 2017). Cuci tangan seharusnya tidak hanya dilakukan ketika mau makan saja. Kebiasaan mencuci tangan juga perlu digerakkan khususnya setelah melakukan buang air besar. Sebanyak $88,6 \%$ responden telah memiliki kebiasaan untuk mencuci tangan setelah buang air besar. Namun, masih dijumpai pula anak yang tidak mencuci tangan setelah buang air besar sebanyak $6,8 \%$.

Frekuensi memotong kuku cukup beragam. Kuku yang panjang dan tidak dipotong secara teratur dapat menjadi tempat bagi telur cacing agar tidak terbawa air ketika prosess mencuci tangan (Junaidi, 2014). Sebesar 79,5\% responden mengaku memiliki kebiasaan memotong kuku 1x dalam 
satu minggu, sedangkan 15,9\% memotong kuku dengan frekuensi 1x tiap 2 minggu. Sebesar 4,5\% memiliki kebiasaan memotong kuku lebih dari 2 minggu sekali. Kebiasaan menggigit kuku masih dijumpai pada responden sebesar 25\%. Sebanyak 9,1\% menyatakan kadang-kadang masih menggigit kuku, sedangkan $65,9 \%$ tidak memiliki kebiasaan ini. Hal ini tentunya juga dapat menjadi salah satu faktor yang menyebabkan masih ditemukannya kecacingan dalam wilayah penelitian ini.

Kebiasaan memakai alas kaki ketika bermain di luar rumah ditanyakan untuk mencari faktor risiko infeksi kecacingan yang port de entre nya melalui kulit seperti cacing tambang yakni Necator americanus dan Ancylostoma sp (Wijaya, 2015). Sebanyak 70,5\% responden telah memiliki kebiasaan menggunakan alas kaki ketika bermain di luar rumah. Namun sayangnya masih dijumpai sebesar 11,4\% responden yang tidak menggunakan alas kaki ketika berada di luar rumah dan 18,2\% responden mengaku terkadang tidak menggunakan alas kaki. Pada penelitian ini, tidak ditemukan telur cacing tambang.

Berdasarkan hasil penelitian didapatkan sebesar 61,4\% responden memiliki kegemaran bermain di sungai. Kebiasaan ini dapat memungkinkan seseorang untuk terinfeksi cacing yang stadium penularannya melalui air seperti kelas trematoda. Bermain di sungai juga dapat memperbesar kemungkinan kontak responden dengan agen infeksi yang ikut bersama dengan kotoran yang dibuang di sungai. Hal ini tidak lepas dari kebiasaan buang air besar yang belum menggunakan jamban. Sebanyak $25 \%$ responden mengaku masih memiliki kebiasaan buang air besar di sungai dan sebanyak $75 \%$ sudah terbiasa buang air besar di jamban. Perilaku buang air besar di sungai dapat mencemari air sungai dengan telur atau stadium infektif lain yang ikut bersamaan dengan kotoran. Jika penderita yang positif mengandung telur cacing melakukan perilaku ini, dapat meningkatkan penyebaran kejadian kecacingan ke penduduk lain (Junaidi, 2015).

Berdasarkan data yang diperoleh selama proses penelitian, didapatkan sebesar $65,9 \%$ responden memiliki perilaku hidup sehat yang baik sedangkan 34,1\% memiliki perilaku hidup sehat yang masuk dalam kategori sedang. Tidak ada responden yang masuk dalam kategori buruk pada penelitian ini. Penelitian serupa yang dilakukan oleh Fitri et al., (2012) di SD di Angkola Timur, Tapanuli Selatan menunjukkan $28 \%$ responden memiliki perilaku hidup sehat yang baik dan $72 \%$ responden memiliki perilaku yang masuk dalam kategori tidak baik.

Hasil uji Chi-square didapatkan $p=0,197(p>0,05)$. Hal ini menunjukkan bahwa tidak terdapat hubungan antara perilaku kebersihan perorangan dengan kejadian kecacingan pada siswa SD Susukan, Kabupaten Sumbang.

Perilaku kebersihan siswa SD Susukan yang berkaitan dengan risiko terjadinya kecacingan, sebagian besar masuk dalam kategori baik. Hal ini terlihat pada persentase perilaku hidup sehat yang baik lebih besar daripada perilaku yang tidak baik. Ditemukannya infeksi kecacingan pada 6,8\% responden dengan perilaku kebiasaan baik kemungkinan disebabkan karena perilaku kebiasaan baik tersebut belum dilakukan dengan metode yang benar, diantaranya adalah perilaku mencuci tangan. Cuci tangan berperan dalam mencegah kesakitan dan penularan berbagai macam penyakit diantaranya kecacingan (Purwandari et al., 2013). Cuci tangan dapat memberikan kontribusi yang besar dalam meningkatkan derajat kesehatan manusia asalkan dilakukan dengan teknik dan sumber air yang tepat (Muthoharoh, et al., 2015). Burton et al., (2011) menyatakan bahwa mencuci tangan dengan sabun lebih efektif dari cuci tangan hanya dengan air dalam hal memindahkan agen penyebab penyakit. Sumber air yang digunakan untuk mencuci tangan yang baik adalah air bersih yang mengalir (Chittleborough et al, 2013). Mencuci tangan yang benar tidak hanya sekedar membasahi tangan, namun juga menggunakan sabun. Tidak hanya bagian 
telapak tangan, mencuci tangan yang baik perlu memperhatikan kebersihan di bagian sela-sela jari dan ujung kuku. Risnawati (2016) menyatakan bahwa mencuci tangan yang benar dilakukan minimal selama 20 detik. Pembiasaan pada metode cuci tangan yang benar sangat penting mengingat kesadaran akan cuci tangan yang bersih pada beberapa kalangan masyarakat masih rendah. Dengan pembiasaan metode cuci tangan yang benar, diharapkan siswa SD bisa terhindar dari infeksi kecacingan di masa yang akan datang (Winita et al., 2012).

Perilaku kebiasaan mencuci tangan siswa SD di Desa Susukan perlu mendapat perhatian. Jika perilaku cuci tangan tidak dilakukan dengan baik, infeksi kecacingan masih dapat terus dijumpai mengingat daerah penelitian memiliki kondisi tanah yang mendukung perkembangan cacing parasit penyebab infeksi pada manusia. Desiyanto dan Sitti (2013) menyatakan bahwa kebiasaan cuci tangan harus dilakukan pada waktu khusus antara lain sebelum mempersiapkan makan, sebelum dan sesudah makan, setelah buang air besar dan buang air kecil, setelah berurusan dengan sampah, setelah bermain atau mengurus binatang peliharaan dan tidak kalah penting juga setelah bersin dan batuk. Pembiasaan cuci tangan dengan baik dan benar perlu dilatih dan ditekankan dari dini agar anak terlindung dari berbagai infeksi yang dapat ditularkan melalui tangan salah satunya yakni kecacingan (Prayoga, 2016).

\section{KESIMPULAN}

Prevalensi kecacingan di SD Susukan, Kecamatan Sumbang, Kabupaten Banyumas adalah 6,8\% dan spesies yang ditemukan pada penelitian ini adalah A. lumbricoides dan Hymenolepis sp. Tidak ditemukan hubungan antara perilaku kebersihan perorangan dengan kejadian kecacingan pada siswa SD Susukan, Sumbang, kabupaten Banyumas $(p=0,197)$.

\section{UCAPAN TERIMAKASIH}

Penulis mengucapkan terimakasih kepada Kepala Sekolah SD Susukan, Kecamatan Sumbang, Kabupaten Banyumas yang telah memberikan ijin dan bantuan terkait teknis selama proses penelitian. Penulis juga mengucapkan terimakasih kepada Fakultas Kedokteran Universitas Jenderal Soedirman yang memberikan kesempatan penulis melakukan penelitian ini.

\section{DAFTAR PUSTAKA}

Aswadi, Sukfitrianty, S., Virgilius, D., Surahmawati. 2017. Perilaku hidup bersih dan sehat (phbs) pada siswa-siswi sd rita pada kecamatan kota komba kabupaten manggarai timur propinsi nusa tenggara timur. Al-Sihah : Public Health Science Journal 9(2) : 187-196.

Bisara, D. dan Mardiana. 2014. Kasus kecacingan pada murid sekolah dasar di kecamatan mentewe, kabupaten tanah bumbu kalimantan selatan tahun 2010. Jurnal Ekologi Kesehatan 13(3): 255-264.

Burton, M., Emma, C., Peter, D., Gaby, J., Val, C., Wolf, P.S. 2011. The effect of handwashing with water or soap on bacterial contamination of hands. International Journal of Environmental Research and Public Health 8: 97-104.

Chadijjah, S., Phetisya, P.F.S., Ni, N.V. 2014. Hubungan pengetahuan, perilaku, dan sanitasi lingkungan dengan angka kecacingan pada anak sekolah dasar di kota palu. Media Litbangkes 24 (1): 50-56. 
Chittleborough,C.R., Alexandra, L.N., elaine, Y., Sarah, B., Rona, C. 2013. Implementation of an educational intervention to improve hand washing in primary schools: process evaluation within a randomised controlled trial. BMC Public Health 13: 757.

Desiyanto, F.A., dan Sitti, N.D. 2013. Efektifitas mencuci tangan menggunakan cairan pembersih tangan antiseptik (hand sanitizer) terhadap jumlah angka kuman. Jurnal Kesehatan Masyarakat 2(2) : 75-82.

Fitri, J., Zulfan, S., Muhammad, Y.H. 2012. Analisis faktor-faktor risiko infeksi kecacingan murid sekolah dasar di Kecamatan Angkola Timur Kabupaten Tapanuli Selatan tahun 2012. Jurnal Ilmu Lingkungan 6(2): 146-161.

Junaidi. 2014. Hubungan personal hygiene terhadap kejadian kecacingan pada murid sd di wilayah kerja puskesmas tapalang kabupaten mamuju. Jurnal Ilmiah Kesehatan Diagnosis 15(1): 108-114.

Manuhutu, R., Dyah U.P., Endo, D. 2017. Pengaruh tingkat konsumsi energi, protein, lemak, dan status kecacingan terhadap status gizi pada siswa Sekolah Dasar Negeri 01 Limpakuwus. Jurnal Kesmas Indonesia 9 (1) : 46-55.

Martila, Semuel, S., Nopita, P. 2015. Hubungan higiene perorangan dengan kejadian kecacingan pada murid SD Negeri Abe Pantai Jayapura. Plasma 1(2) : 87-96.

Muthoharoh, S., Djauhar, I., Muhammad, H. 2015. Perilaku mencuci tangan dan kejadian kecacingan pada siswa Sekolah Dasar Di Kecamatan Petanahan Kabupaten Kebumen. Jurnal Ilmiah Kesehatan Keperawatan 11(2) : 51-59.

Prayoga, T.Y. 2016. Hubungan perilaku cuci tangan dengan kejadian cacingan pada anak Sekolah Dasar Di SD N 1 Tangkup Sidemen Karangasem. Skripsi. Universitas Udayana.

Purwandari, R., Anisah, A., Wantiyah. 2013. Hubungan antara perilaku mencuci tangan dengan insiden diare pada anak usia sekolah di Kabupaten Jember. Jurnal Keperawatan 4(2) : 122-130.

Risnawati, G. 2016. Faktor perilaku Cuci Tangan Pakai Sabun (CTPS) pada masyarakat di Tanah Kalikedinding. Jurnal Promkes 4(1): 70-81.

Sandy, S., Sri, S., Soeyoko. 2015. Analisis model faktor risiko yang mempengaruhi infeksi kecacingan yang ditularkan melalui tanah pada siswa Sekolah Dasar Di Distrik Arso Kabupaten Keerom, Papua. Media Litbangkes 25 (1) : 1 - 14.

Sardjono, T.W., Aswin, D.B., Sri, P. 2017. Helmintologi Kedokteran dan Veteriner. Malang. UB Press.

Thomas, C., Shopi, B., Parimita, R., Bellen, T., Melisa,B., Oliver, C., et al. 2014. Effectiveness of a rural sanitation programme on diarrhoea, soil-transmitted helminth infection, and child malnutrition in Odisha, India: a cluster-randomised trial. The Lancet Global Health 2(11): 645-653. 
Vercruysse, J., Jerzy, M.B., Marco, A., Shaali, M.A., Cecile, A., Jeffrey, M.B., et al. 2011. Assessment of the anthelmintic efficacy of albendazole in school children in seven countries where soil-transmitted helminths are endemic. PLoS Negl Trop Dis 5(3): e948.

Wijaya, N.H. 2015. Beberapa faktor risiko kejadian infeksi cacing tambang pada petani pembibitan albasia (studi kasus di Kecamatan Kemiri). Tesis. Universitas Diponegoro Semarang.

Winita, R., Mulyati, Hendri, A. 2012. Upaya pemberantasan kecacingan di sekolah dasar. Makara Kesehatan 16(2): 65-71.

Yusriati. 2016. Pengaruh karakteristik ibu, PHBS dan sanitasi lingkungan terhadap kecacingan pada balita di Desa Kuala Langsa Kecamatan Langsa Barat Kota Langsa. Tesis. Universitas Sumatra Utara.

Ziegelbauer, K., Speich, B., Mäusezahl, D., Bos, R., Keiser, J., Utzinger, J. 2012. Effect of sanitation on soil-transmitted helminth infection: systematic review and meta-analysis. PLoS Med 9(1): e1001162. 